\title{
The Total Phenolic Contents and Antioxidant Activities of Endemic Species Ajuga postii Briq. and Ajuga relicta P.H.Davis (Lamiaceae) from Turkey
}

\author{
Emel Sönmez*, Yavuz Bülent Köse \\ Anadolu University, Faculty of Pharmacy, Department of Pharmaceutical Botany, 26470 Eskişehir, TURKEY.
}

\begin{abstract}
Background: Ajuga species are anthelmintic, diuretic, antifungal, and antimycobacterial agents.Lamiaceae members Ajuga postii Briq. and Ajuga relicta P.H.Davis are local endemic species of Turkey. Aim: To give information about the total phenolic contents and antioxidant activities of the species. Methods: The total phenolic contents of the extracts have been quantified with Folin Ciocalteu colorimetric method, and the antioxidant activities of the extracts have been tested with DPPH, ABTS, and $\beta$-carotene / Linoleic acid assays. Results: Deodorized water extracts of the two species have been observed with the highest phenolic contents. $70 \%$ methanol extracts of $A$. relicta have the highest rates for the three antioxidant activity tests. However, different extracts of $A$. postii have been observed with different activity rates in all three antioxidant assays. Conclusion: The species are in restricted areas and can become extinct over time, therefore important of the study increases.
\end{abstract}

Key words: ABTS, Ajuga, $\beta$-Carotene / Linoleic Acid Assay, DPPH, Total Phenolic Content.

\section{INTRODUCTION}

Reactive oxygen species (ROS) are natural byproducts of oxygen for instance peroxides, superoxide, hydroxyl radical and singlet oxygen, and cause to cancer, agerelated and pathogenesis diseases. ${ }^{1}$ These destructive effects caused by oxygen are eliminated with antioxidants. Plant species have phenolic compounds and act as antioxidant agents. ${ }^{2}$ Phenols, alkaloids, triterpenoids result from the secondary metabolites of the plants and protect the plants against pathogens, UV radiation and herbivorous. ${ }^{3}$ As antioxidants, not only phenolic compounds got from plants are used but also produced products. BHT (Butylatedhydroxytoluene) and BHA (Butylatedhydroxyanisole) are the produced antioxidants, but they cause damage to the liver. $^{4}$

Lamiaceae is known as the antioxidant and antimicrobial agent. Therefore, the species of the family are used in pharmacy and cos- metic industry, ${ }^{5}$ and as antibacterial agents to extend the shelf life of the meat and fish products. ${ }^{3}$ Ajuga L. is one of the members of Lamiaceae. Ajuga is used as anthelmintic, diuretic, antifungal, anti-inflammatory and antimycobacterial agents; used for fever, toothache, dysentery, malaria, hypertension, diabetes and gastrointestinal disorders in traditional medicine. ${ }^{6-10}$ Thus, discussed effects result from chemical contents of the species. The found chemicals are phytoecdysteroids, diterpenoids, triterpenes, anthocyanidin-glucosides, iridoid glycosides, flavonoids and essential oils. ${ }^{11}$ Ajuga has represented to 13 species and 10 subspecies in Turkey. ${ }^{12}$

Ajuga postii Briq. and Ajuga relicta P.H.Davis are local endemic species of Turkey. The species were studied for iridoid glucoside reptoside, ${ }^{13}$ four steroids, two triterpenoids, two diterpenoids, monoterpene, and iridoid. ${ }^{14}$ In the present study, the total
Submission Date: 15-03-2017; Revision Date: 23-03-2017; Accepted Date: 10-04-2017

DOI: 10.5530/ijper.51.4.103 Correspondence: Emel Sönmez, Anadolu University, Faculty of Pharmacy, Department of Pharmaceutical Botany, 26470, Eskişehir, TURKEY. Tel: +90 (222) $3350580 /$ 3703;

Fax: +90(222) 3350750

E-mail: emels@anadolu. edu.tr

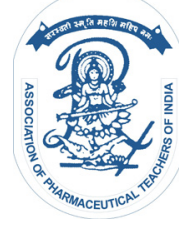

www.ijper.org 
phenolic contents and antioxidant activities of $A$. postii and $A$. relicta extracts have been studied for the first time. The important of the study is taxa are found in limited areas and can become extinct in the years. The aim of the paper is to give information about the total phenolic contents and antioxidant activities of the species for the pharmacological studies.

\section{MATERIALS AND METHODS}

\section{Plant materials}

The aerial parts of $A$. postii were collected from İçel: Çamliyayla, Namrun Castle, $1350 \mathrm{~m}, \mathrm{~K} 37^{\circ} 16.8^{\prime} 54.5^{\prime \prime} \mathrm{D}$ $34^{\circ} 60.1^{\prime} 16.5$ '(10.07.2015) and aerial parts of $A$. relicta were collected from Kahramanmaraş: Çimen Mountain, Yavşan Hill, Pekmezpınarı, 1500 m, K 37 28' 42" D $36^{\circ}$ $42^{\prime} 21^{\prime \prime}(03.06 .2015)$. The plant materials were dried at room temperature in the shadows.

\section{Preparation of the extracts}

Powdered dried aerial parts of the plants were extracted in Soxhlet apparatus for hexane, ethyl acetate, and methanol about 8 hours for each solvent. The extracts were concentrated in rotavapor $\left(<40^{\circ} \mathrm{C}\right) .70 \%$ methanol extracts and deodorized waters of plant materials were lyophilized. All the extracts were stored at $-20^{\circ} \mathrm{C}$ until the analyses (1A (hexane extract of $A$. relicta), 1B (ethyl acetate extract of $A$. relicta), 1C (methanol extract of A. relicta), 2A (70\% methanol extract of $A$. relicta), 2B (deodorized water of $A$. relicta), 3A (hexane extract of $A$. postii), 3B (ethyl acetate extract of $A$. postii), 3C (methanol extract of $A$. postii), 3D (70\% methanol extract of $A$. postii), 3E (deodorized water of $A$. postii).

\section{Determination of the total phenolic contents}

The total phenolic contents of the extracts were quantified with using Folin-Ciocalteu colorimetric method. All samples and gallic acid as standard were dissolved in the methanol. $50 \mu \mathrm{L}$ of the sample, $4 \mathrm{ml}$ of distilled water, $250 \mu \mathrm{L}$ Folin-Ciocalteu reagents and $750 \mu \mathrm{L}$ sodium carbonate solution $\left(\mathrm{Na}_{2} \mathrm{CO}_{3}\right)$ were incubated at room temperature for $2 \mathrm{~h}$. The sample absorbances were read at $760 \mathrm{~nm}$ in the spectrophotometer. The amount of the total phenolic contents were calculated as milligrams of the gallic acid equivalents (mg GAE/g extract).

Antioxidant activity

$\mathrm{DPPH} \cdot$ radical scavenging activity
The effects of the samples on 1,1-diphenyl-2-pipicrylhydrazyl (DPPH) radical was estimated according to Uysaland Aktumsek $2 \mathrm{mg} / 25 \mathrm{~mL} \mathrm{DPPH} \bullet$ was prepared in methanol. ${ }^{2}$ Diluted samples and DPPH solution was read at $517 \mathrm{~nm}$ in the spectrophotometer after a 30 min incubation at room temperature in the dark. The ability to scavenge the DPPH radical was calculated with the following equation:

$\mathrm{DPPH} \bullet$ Scavenging Effect $\%=\left[\left(\mathrm{A}_{0}-\mathrm{A}_{1}\right) / \mathrm{A}_{0}\right] \times 100$

$A_{0}$ is the absorbance of the control and $A_{1}$ is the absorbance of the sample. The $\mathrm{IC}_{50}$ values are concentrations of extracts causing $50 \%$ inhibition of DPPH radical. Lower $\mathrm{IC}_{50}$ value shows high antioxidant activity.

\section{ABTS•+ radical scavenging activity}

ABTS $\bullet+$ was produced by $7 \mathrm{mM}$ ABTS (2,2'-azinobis-(3-ethyl-benzothiazoline-6-sulfonate) with $2.5 \mathrm{mM}$ sodium persulfate $\left(\mathrm{Na}_{2} \mathrm{~S}_{2} \mathrm{O}_{8}\right)$ and mixture to stand for 12-16 hours in the dark at room temperature. ABTS $\bullet$ solution was diluted with ethanol to be absorbance 0.8 to 0.7 at $734 \mathrm{~nm}$ in the spectrophotometer. $10 \mu \mathrm{L}$ sample solution was mixed with $990 \mu \mathrm{L}$ ABTS •+ solution. The absorbances of samples were read at $734 \mathrm{~nm}$ in the spectrophotometer after $30 \mathrm{~min}$ incubation at room temperature. ${ }^{15}$

\section{$\beta$-carotene / Linoleic acid assay}

$1 \mathrm{mg} \beta$-carotene was dissolved in $1 \mathrm{ml}$ chloroform, 120 $\mathrm{mg}$ linoleic acid and $1200 \mathrm{mg}$ Tween 20 were added. Chloroform was removed using rotavapor, the mixture was concentrated with nitrogen for $10 \mathrm{~min}$. Adding 300 $\mathrm{ml}$ distilled water was shaken for $10 \mathrm{~min}$. The absorbance of the mixture was measured at $470 \mathrm{~nm}$. Antioxidant activities of the extracts were compared with butylated hydroxytoluene (BHT). ${ }^{16}$

\section{RESULTS}

\section{The total phenolic contents}

In the present study, hexane, ethyl acetate, methanol, $70 \%$ methanol extracts and deodorized waters of two Ajuga species were investigated. The total phenolic contents of $A$. postii and $A$. relicta were determined with Folin-Ciocalteu method with equivalent to gallic acid. Orders of the extracts from small to large were hexane extract of $A$. relicta $<$ ethyl acetate extract of $A$. relicta $<$ hexane extract of $A$. postii< ethyl acetate extract of $A$. postii< methanol extract of $A$. relicta $<$ methanol extract of $A$. postii< $70 \%$ methanol extract of $A$. postii< $70 \%$ methanol extract of $A$. relicta< 
deodorized water of $A$. relicta $<$ deodorized water of A. postii (Figure 1).

\section{Antioxidant activity}

The antioxidant activities of the two Ajuga species were determined with $\mathrm{DPPH} \bullet$, ABTS $\bullet+$ free radical scavenging, and $\beta$-carotene/Linoleic acid assays. In $\mathrm{DPPH}$ experiment, the results were given as $\mathrm{IC}_{50}$ values at tested concentrations and compared with standard gallic acid values. Low $\mathrm{IC}_{50}$ values have high antioxidant activities in $\mathrm{DPPH} \bullet$ scavenging activity. The orders of the extracts were GA $>70 \%$ methanol extract of $A$. relicta>deodorized water of $A$. postii $>70 \%$ methanol extract of $A$. postii>methanol extract of $A$. relicta $>$ hexane extract of $A$. postii $>$ methanol extract of $A$. postii>deodorized water of $A$. relicta $>$ hexane extract of $A$. relicta $>$ ethyl acetate extract of $A$. relicta $=$ ethyl acetate extract of $A$. postii (Figure 2).

ABTS + (TEAC) assay was applied to figure ABTS (2,2'-azinobis-(3-ethyl-benzothiazoline-6-sulfonate) free radical scavenging activities of the extracts. In the present paper, Butylated hydroxytoluene (BHT) and gallic acid (GA) were used to control. The orders of the extracts were $\mathrm{BHT}=\mathrm{GA}>70 \%$ methanol extract of $A$. relicta $>70 \%$ methanol extract of $A$. postii $>$ deodorized water of $A$. relicta $>$ methanol extract of $A$. relicta $>$ methanol extract of $A$. postii>ethyl acetate extract of $A$. postii> hexane extract of $A$.postii>deodorized water

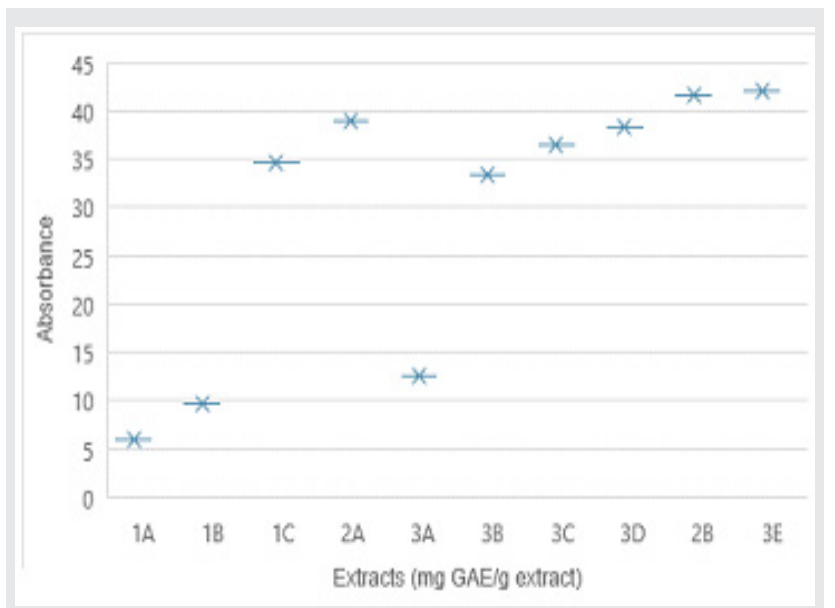

Figure 1: The amount of the total phenolic contents of Ajuga extracts.

1A (hexane extract of A. relicta), 1B (ethyl acetate extract of A. relicta), 1C (methanol extract of A. relicta), $2 A(70 \%$ methanol extract of $A$. relicta), 3A (hexane extract of $A$. postii), 3B (ethyl acetate extract of A. postii), 3C (methanol extract of A. postii), 3D ( $70 \%$ methanol extract of $A$. postii), 2B (deodorized water of A. relicta), 3E (deodorized water of $A$. postii) of $A$. postii $>$ ethyl acetate extract of $A$. relicta $>$ hexane extract of $A$. relicta (Figure 3).

Linoleic acid is a model lipid for peroxidation. Prevention of the $\beta$-carotene fading result from the high antioxidant activity. Antioxidant values of the studied extracts were deodorized water of $A$. relicta $<$ deodorized water of $A$. postii $<$ hexane extract of $A$. relicta $<$ ethyl acetate extract of $A$. relicta $<$ ethyl acetate extract of $A$. postii $<70 \%$ methanol extract of $A$. postii< methanol extract of $A$. postii< hexane extract of $A$. postii< $<$ methanol extract of A. relicta $<70 \%$ methanol extract of $A$. relicta $<$ BHT (Figure 4).

\section{DISCUSSION}

\section{The total phenolic contents}

The phenols are the secondary metabolites of the plants, are good at scavenging of the free radicals. ${ }^{1}$ In the present study, the highest total phenolic contents were determined on deodorized waters of $A$. postii and $A$. relicta (Figure 1). In the other study, extracts of $A$. orientalis L. were investigated for the total phenolic contents and antioxidant activities, ${ }^{17}$ the highest phenolic content and antioxidant activities were found in methanol extracts.

In the literature, the total phenolic content of the methanolic extract of $A$. iva L. was reported 26.86 (mg GAE/g extract). ${ }^{4}$ In the present study, the results of the phenolic contents of the methanolic extracts were

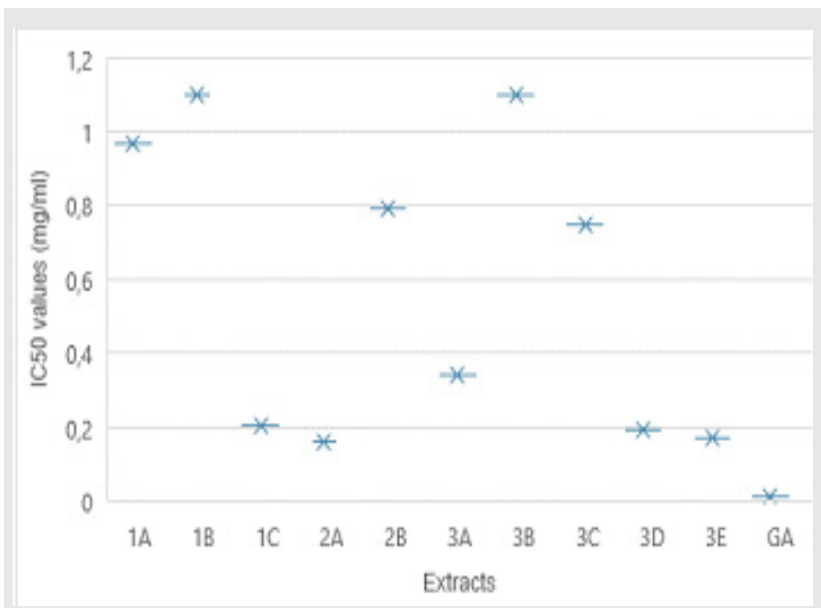

Figure 2: DPPH • free radical scavenging effects of Ajuga extracts.

$1 \mathrm{~A}$ (hexane extract of A. relicta), 1B (ethyl acetate extract of $A$. relicta), $1 C$ (methanol extract of $A$. relicta), $2 A(70 \%$ methanol extract of $A$. relicta), $2 B$ (deodorized water of $A$. relicta), 3A (hexane extract of $A$. postii), 3B (ethyl acetate extract of A. postii), 3C (methanol extract of A. postii), 3D (70\% methanol extract of A. postii), 3E (deodorized water of A. postii), GA (Gallic acid) 


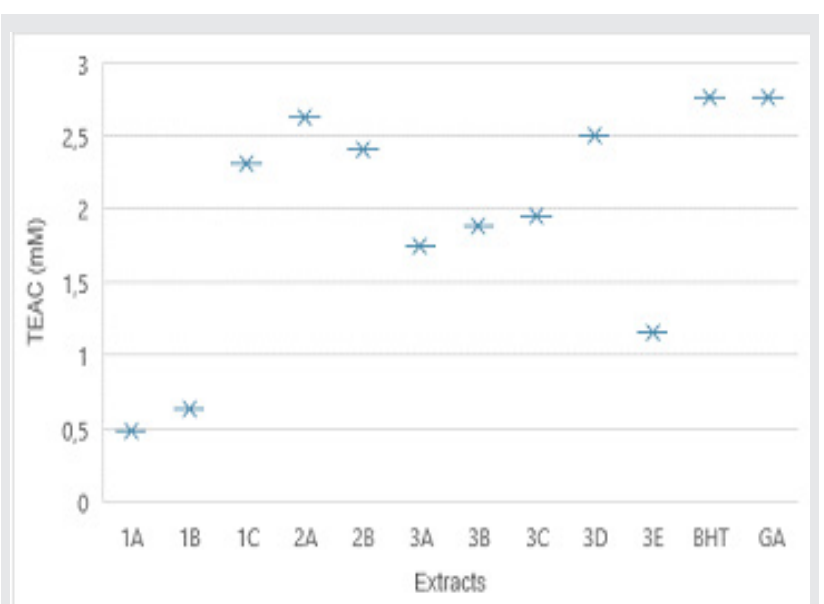

Figure 3: The results of ABTS-+.

$1 \mathrm{~A}$ (hexane extract of A. relicta), 1B (ethyl acetate extract of A. relicta), $1 C$ (methanol extract of A. relicta), $2 A(70 \%$ methanol extract of A. relicta), 2B (deodorized water of A. relicta), 3A (hexane extract of $A$. postii), 3B (ethyl acetate extract of A. postii), 3C (methanol extract of A. postii), 3D (70\% methanol extract of A. postii), 3E (deodorized water of A. postii), BHT (Butylatedhydroxytoluene), GA (Gallic acid).

34.6 (A. relicta) (mg GAE/g extract) and 36.5 (A. postii) (mg GAE/g extract). In the other study, the increase in the antioxidant activity was associated with the higher content of phenolic substances. ${ }^{1}$ Thus, the phenolic contents result from biological and environmental conditions. ${ }^{18}$

\section{Antioxidant activity}

The plants have complex phytochemical compounds so multiple antioxidant activity assays were performed in the present study. DPPH $\bullet$ method is used for anion radicals and ABTS $\bullet+$ is used for cation radicals. $\mathrm{DPPH} \bullet$ is a stable free radical, the largest absorbance occurs at $517 \mathrm{~nm}$ and when faced with antioxidants free radicals scavenged and their absorbances decrease. ${ }^{19}$ Scavenging activity of DPPH radical was tested in the earlier study for $A$. iva and found result of $\mathrm{IC}_{50}$ of methanolic extract was $1.168 \mathrm{mg} / \mathrm{ml}$ and was $0.72 \mathrm{mg} / \mathrm{ml}$ for essential oil of $A$. pseudoiva Rob. ${ }^{4,19}$ In the present paper, $\mathrm{IC}_{50}$ values were $0.205 \mathrm{mg} / \mathrm{ml}$ (A. relicta) and $0.75 \mathrm{mg} / \mathrm{ml}$ (A. postii). Hence, studied extracts had high antioxidant activities. In the other study, the water extract of $A$. chamaepitys (L.) Schreber had the highest result. ${ }^{1}$ In the present study, $70 \%$ methanol extract of $A$. relicta and deodorized water extract of $A$. postii had the highest values.

ABTS (2,2'-azinobis-(3-ethyl-benzothiazoline-6-sulfonate) is the other free radical. In the ABTS $\bullet+(T E A C)$ scavenging assay, the highest $\mathrm{ABTS} \bullet+$ results were observed in $70 \%$ methanol extracts of the two species.

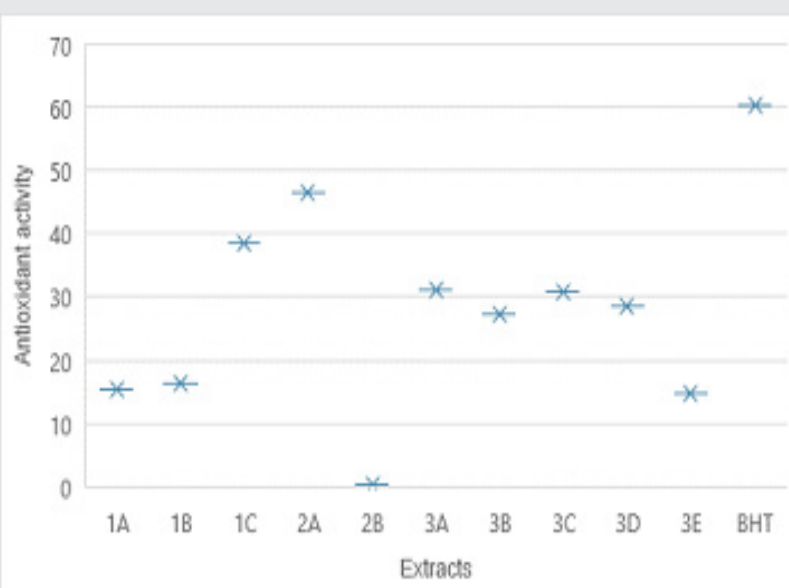

Figure 4: Antioxidant activities of the Ajuga extracts in $\beta$-carotene-Linoleic acid test.

$1 \mathrm{~A}$ (hexane extract of $\mathrm{A}$. relicta), 1B (ethyl acetate extract of A. relicta), 1C (methanol extract of A. relicta), $2 A(70 \%$ methanol extract of $A$. relicta), 2B (deodorized water of $A$. relicta), 3A (hexane extract of A. postii), 3B (ethyl acetate extract of A. postii), 3C (methanol extract of A. postii), 3D ( $70 \%$ methanol extract of A. postii), 3E (deodorized water of A. postii), BHT (Butylatedhydroxytoluene)

In the other study, ABTS $\bullet+$ radical scavenging capacities of the methanol, water, and chloroform extracts of $A$. chamaepitys were studied, and the highest rate was found in the water extract. ${ }^{1}$

In the $\beta$-carotene-Linoleic acid assay, colored $\beta$-carotene results from the high antioxidant activity. In the present study, $70 \%$ methanol extract of $A$. relicta and hexane extract of $A$. postii had the highest rates in the experiment. In the other study, as the essential oil concentration of $A$. pseudoiva increased, the $\beta$-carotene-Linoleic acid activity also increased. ${ }^{19}$

\section{CONCLUSION}

To the best of our knowledge, the total phenolic contents and antioxidant activities of $A$. postii and $A$. relicta have not been reported. The results of the study show deodorized water extracts of $A$. postii and $A$. relicta have the highest phenolic contents. In the DPPH• assay, the highest value for $A$. postii is deodorized water extract (3E) and for $A$. relicta is $70 \%$ methanol extract. In the TEAC assay, $70 \%$ methanol extracts of $A$. postii (3D)and A. relicta (2A)have the highest rates and in the Beta-carotene / Linoleic acid inhibition test, the highest values are $70 \%$ methanol extract of $A$. relicta (2A) and hexane extract of $A$. postii (3A). In the literature studies, antioxidant activity assays give the similar results with the total phenolic contents of the plants, but in the present study the same results have not been observed. In the present paper, the highest phenolic contents have 
been observed in deodorized water extracts of $A$. postii and $A$. relicta, in the antioxidant activity assays $70 \%$ methanol extracts of $A$. relicta have the highest rates for all three tests, but different extracts of $A$. postii have the highest values for the three antioxidant assays.

\section{ACKNOWLEDGEMENT}

The study has been supported by Anadolu University Scientific Research Committee (Project No. 1501S009). Also, the authors are thankful to Dr. Fatih Göger.

\section{CONFLICT OF INTEREST}

The authors declare that there is no conflict of interest.

\section{ABBREVIATION USED}

$\mu \mathrm{L}:$ Microliter (10-6 litre); ABTS•+: 2,2'-azinobis(3-ethyl-benzothiazoline-6-sulfonate); BHT: Butylated hydroxytoluene; DPPH': 1,1-diphenyl-2-pipicrylhydrazyl; g: Gram; GAE: Gallic acid equvalent; h: Hour; IC $_{50:}$ The concentration of an inhibitor where the response (or binding) is reduced by half; mg: Milligram; ml: Milliliter; mM: Millimolar; nm: Nanometer; TEAC: Trolox equivalent antioxidant capacity; Tween ${ }^{\circledR}$ 20: Polyethylene glycol sorbitan monolaurate.

\section{REFERENCES}

1. Turkoglu S, Turkoglu I, Kahyaoglu M, Celık S. Determination of antimicrobial and antioxidant activities of Turkish endemic Ajuga chamaepitys (L.) Schreber subsp. euphratica P.H. Davis (Lamiaceae). J Med Plants Res. 2010;4:1260-8.

2. Uysal S, Aktumsek A. A phytochemical study on Potentilla anatolica: An endemic Turkish plant. Ind Crops Prod. 2015;76:1001-7. https://doi. org/10.1016/j.indcrop.2015.08.017.

3. Trivellini A, Lucchesini M, Maggini R, Mosadegh H, Villamarin TSS, Vernieri $\mathrm{P}$ et al. Lamiaceae phenols as multifaceted compounds: bioactivity, industrial prospects and role of "positive-stress". Ind Crops Prod. 2016;83:241-54. https://doi.org/10.1016/j.indcrop.2015.12.039.

4. Khaled-Khodja N, Boulekbache-Makhlouf L, Madani K. Phytochemical screening of antioxidant and antibacterial activities of methanolic extracts of some Lamiaceae. Ind Crops Prod. 2014;61:41-8. https://doi.org/10.1016/j. indcrop.2014.06.037.

5. Draughon FA. Use of botanicals as biopreservatives in foods. Food Technol. 2004;58:20-8.

6. Ziyyat A, Legssyer A, Mekhfi H, Dassouli A, Serhrouchni M, Benjelloun W. Phytotherapy of hypertension and diabetes in oriental Morocco. J Ethnopharmacol. 1997;58(1):45-54. https://doi.org/10.1016/S03788741(97)00077-9.

7. Muthaura CN, Rukunga GM, Chhabra SC, Mungai GM, Njagi ENM. Traditional Phytotherapy of Some Remedies Used in Treatment of Malaria in Meru District of Kenya. S Afr J Bot. 2007;73(3):402-11. https://doi. org/10.1016/j.sajb.2007.03.004.

8. Sarac N, Ugur A. Antimicrobial activities and usage in folkloric medicine of some Lamiaceae species growing in Mugla, Turkey. EurAsia J Bio Sci. 2007;4:28-37.

9. Güneş F, Özhatay N. An ethnobotanical study from Kars (Eastern) Turkey. Bio Di Con. 2011;4(1):30-41.

10. Keter LK, Mutiso PC. Ethnobotanical studies of medicinal plants used by Traditional Health Practitioners in the management of diabetes in Lower Eastern Province, Kenya. J Ethno Pharmacol. 2012;139(1):74-80. https://doi. org/10.1016/j.jep.2011.10.014; PMid:22020309.

11. Israili ZH, Lyoussi B. Ethnopharmacology of the Plants of Genus Ajuga. Pak J Pharm Sci. 2009;22(4):425-62. PMid:19783524.

12. Gören AC, Zhou BN, Topcu G, Kökdil G, Kingston DGI. DNA Damaging Activities of Methanol Extract of Ajuga postii and Iridoid Glucoside Reptoside. Nat Prod Rep. 2005;19(5):457-60. https://doi.org/10.1080/14786410412331 272095 ; PMid:15938192.

13. Kökdil G, Topcu G, Goren AC, Voelterd W. Steroids and Terpenoids from Ajuga relicta. Z Naturforsch B. 2002;57(8):957-60.

14. Re R, Pellegrini N, Proteggente A, Pannala A, Yang M, Rice-Evans C. Antioxidant activity applying an improved ABTS radical cation decolorization assay. Free RadicBiol Med. 1999;26(9):1231-7. https://doi.org/10.1016/ S0891-5849(98)00315-3.

15. Karaosmanoğlu H, Soyer F, Ozen B, Tokatlı F. Antimicrobial and Antioxidant Activities of Turkish Extra Virgin Olive Oils. J Agric Food Chem. 2010;58:823845. https://doi.org/10.1021/jf1012105; PMid:20604567.

16. Göger F, Köse YB, Göger G, Demirci F. Phytochemical characterization of phenolics by LC-MS/MS and biological evaluation of Ajuga orientalis from Turkey. Bangladesh J Pharmaco. 2015;10(3):639-44. https://doi.org/10.3329/ bjp.v10i3.23500.

17. Ksouri R, Megdiche W, Falleh H, Trabelsi N, Boulaaba M, Smaoui A et al. Influence of biological, environmental and technical factors on phenolic content and antioxidant activities of Tunisian halophytes. C R Biol. 2008;331(11):86573. https://doi.org/10.1016/j.crvi.2008.07.024 ; PMid:18940702.

18. Mansour MB, Balti R, Rabaoui L, Bougatef A, Guerfel M. Chemical composition, angiotensin I-converting enzyme (ACE) inhibitory, antioxidant and antimicrobial activities of the essential oil from south Tunisian Ajuga pseudoiva Rob. Lamiaceae. Process Biochem. 2013;48(4):723-9. https://doi. org/10.1016/j.procbio.2013.02.022.

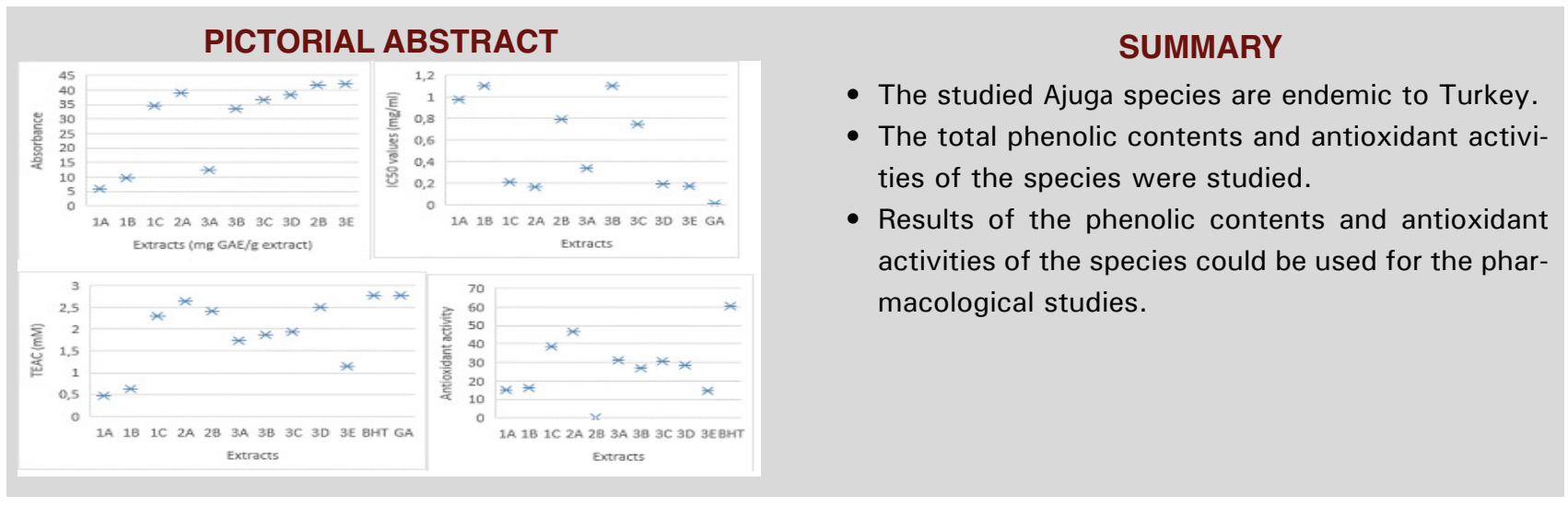




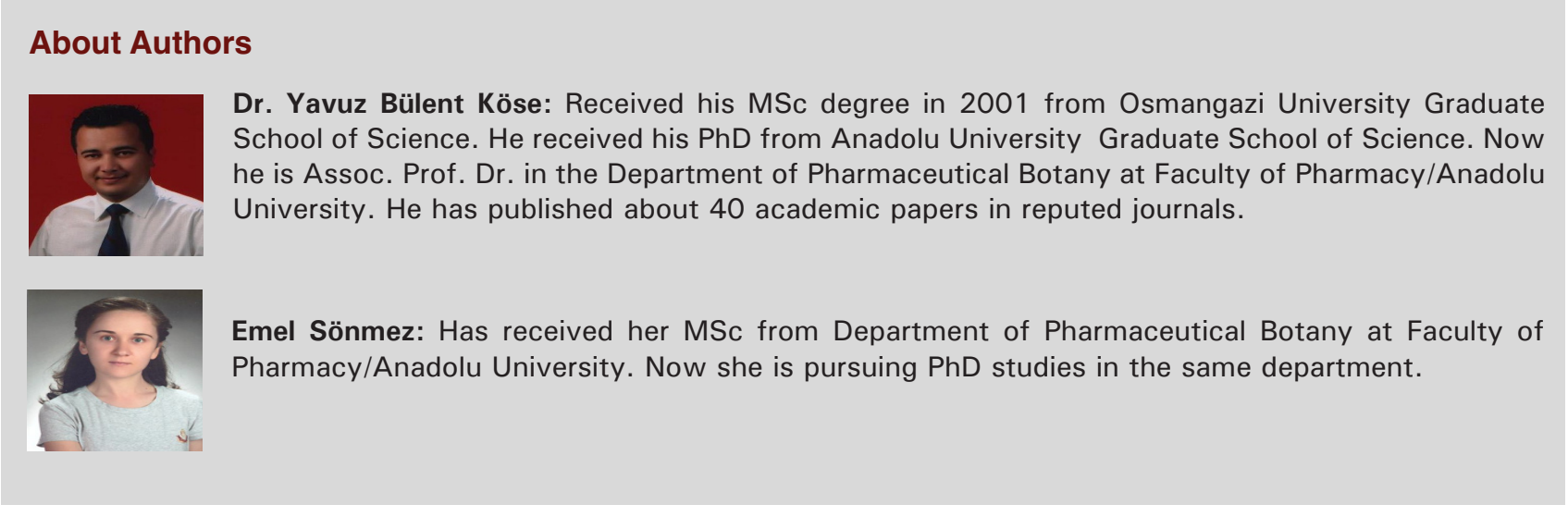

Cite this article: Sönmez E, Köse YB. The total phenolic contents and antioxidant activities of endemic species Ajuga postii Briq. and Ajuga relicta P.H.Davis (Lamiaceae) from Turkey. Indian J of Pharmaceutical Education and Research. 2017;51(4):700-5. 